\title{
Stable isotope evidence from formalin-ethanol-preserved specimens indicates dietary shifts and increasing diet overlap in Lake Victoria cichlids
}

\author{
Mary A. Kishe-Machumu • Jacco C. van Rijssel • Amanda Poste • \\ Robert E. Hecky $\cdot$ Frans Witte
}

Received: 10 January 2016/Revised: 14 July 2016/ Accepted: 17 July 2016/Published online: 8 August 2016

(C) The Author(s) 2016. This article is published with open access at Springerlink.com

\begin{abstract}
Stable isotopes are increasingly being used to infer past and present trophic interactions in light of environmental changes. The Lake Victoria haplochromine cichlids have experienced severe environmental changes in the past decades that, amongst others, resulted in a dietary shift towards larger prey. We investigated how the changed environment and diet of the haplochromines influenced stable isotope values of formalin-then-ethanol-preserved cichlid specimens, and then investigated how these values differed among species before (1977-1982) and after substantial environmental
\end{abstract}

Mary A. Kishe-Machumu and Jacco C. van Rijssel contributed equally to this paper.

Guest editors: S. Koblmüller, R. C. Albertson, M. J. Genner, K. M. Sefc \& T. Takahashi / Advances in Cichlid Research II: Behavior, Ecology and Evolutionary Biology

Electronic supplementary material The online version of this article (doi:10.1007/s10750-016-2925-1) contains supplementary material, which is available to authorized users.

M. A. Kishe-Machumu

Tanzania Fisheries Research Institute, Dar es Salaam, Tanzania

J. C. van Rijssel · F. Witte

Institute of Biology Leiden, Leiden University, Leiden,

The Netherlands

J. C. van Rijssel · F. Witte

Naturalis Biodiversity Center, Leiden, The Netherlands changes (2005-2007). We found a small preservation effect on both $\delta^{13} \mathrm{C}$ and $\delta^{15} \mathrm{~N}$ values, and significant differences in isotope values among haplochromine species collected before the environmental changes. In contrast, there was a remarkable similarity in $\delta^{13} \mathrm{C}$ and $\delta^{15} \mathrm{~N}$ values among species collected from the contemporary ecosystem and two out three species showed significantly different stable isotope values compared to species of the historic ecosystem. In addition, we found a putative isotopic gradient effect along our 5-km-long research transect indicating that the studied demersal species are more stenotopic than previously thought. The environmental changes have resulted in dietary change and overlap of the haplochromines which provides insight into the trophic plasticity of these species, which are often considered trophic specialists.

Keywords Detritivores - Environmental changes · Phytoplanktivores · Stenotopic · Trophic guild · Zooplanktivores

Present Address:

J. C. van Rijssel ( $\square)$

Fish Ecology and Evolution, EAWAG Center of Ecology, Evolution and Biogeochemistry, Kastanienbaum, Switzerland e-mail: jacco.vanrijssel@eawag.ch

J. C. van Rijssel

Institute of Ecology and Evolution, University of Bern, Bern, Switzerland 


\section{Introduction}

The indigenous biodiversity of freshwater ecosystems is declining rapidly (Dudgeon et al., 2006) and the most influential drivers are thought to be climate change and eutrophication (Heino et al., 2009; Smith \& Schindler, 2009). Therefore, a better understanding of effects of these drivers will be essential for conserving and restoring freshwater ecosystems. Freshwater ecosystem restoration efforts have been increasingly incorporating a food web perspective since food web dynamics strongly influence biodiversity and ecosystem functioning (Vander Zanden et al., 2006; Woodward, 2009). Food web studies are now successfully using stable isotope data obtained from museum specimens to infer past and present trophic interactions in the light of environmental changes (Vander Zanden et al., 2003; Schmidt et al., 2009; Nakazawa et al., 2010).

Environmental changes such as species invasions, increased primary productivity and eutrophication are known to influence fish species diversity, niche overlaps and dietary shifts (Seehausen et al., 1997a, b; Winemiller, 1989; Eby et al., 2006). Eutrophication can, for instance, alter the ecological and reproductive niche space by increasing water turbidity and thereby hampering sexual selection leading to the loss of fish diversity (Seehausen et al., 1997a, b). Eutrophication can also result in benthic oxygen depletion thereby changing zoobenthos densities and forcing benthic fish species to move from the profundal to the littoral zone, resulting in dietary and morphological overlap with littoral species (Vonlanthen et al., 2012). Environmental changes in the form of invasive predators often simplify entire food webs, shift community compositions and induce dietary shifts in native species (Goldschmidt et al., 1993; Flecker \& Townsend, 1994; Simon \& Townsend, 2003). For example, Vander Zanden et al. (1999)

\section{A. Poste}

Department of Biology, University of Waterloo, Waterloo, ON, Canada

A. Poste

Norwegian Institute for Water Research, Oslo, Norway

R. E. Hecky

Large Lakes Observatory, University of Minnesota, Duluth, MN, USA found that native lake trout shifted their diets from fish towards zooplankton in response to the presence of invading bass.

During the past three decades, Lake Victoria has endured several profound environmental changes that include eutrophication and species invasion and therefore provides an excellent opportunity to study the effects of environmental changes on fish species. During the mid- and late 1980s, the introduced Nile perch became very abundant in the lake (Pringle, 2005). At the same time, eutrophication resulted in increased phytoplankton blooms, particularly of cyanobacteria (Hecky, 1993; Ochumba \& Kibaara, 1989). These blooms caused low water transparency and low dissolved oxygen levels (Hecky et al., 1994; Mugidde, 1993; Seehausen et al., 1997a; Witte et al., 2005). Concurrently, a higher abundance of shrimps, molluscs, insects and small cyprinid fish (dagaa) was observed (Kaufman, 1992; Wanink, 1999; Goudswaard et al., 2006; van Rijssel et al., 2015). All of these environmental changes are thought to have contributed to the dramatic decline of haplochromine cichlid diversity during the late 1980s (Witte et al., 1992b; Seehausen et al., 1997b).

During the 1990s, a resurgence of some haplochromines was observed (Seehausen et al., 1997b; Witte et al., 2000; Balirwa et al., 2003; Witte et al., 2007). However, the recovering detritivorous and zooplanktivorous cichlids species had shifted their diet to larger and more robust prey such as insects, shrimps, molluscs and small fish (van Oijen \& Witte, 1996; Katunzi et al., 2003; Kishe-Machumu et al., 2008; Kishe-Machumu, 2012; van Rijssel et al., 2015). In addition, there is more overlap of food items in the diets of the haplochromine species, and those of trophic groups, than observed historically (KisheMachumu et al., 2008; Kishe-Machumu, 2012). These studies were based on stomach and gut content analyses and although such methods are useful for establishing details on the types and amounts of prey consumed, they are only representative of diet for the period soon before the sampling event (Gearing, 1991; Hesslein et al., 1993). When stomach and gut content analyses are complemented by analyses of stable nitrogen $\left(\delta^{15} \mathrm{~N}\right)$ and carbon $\left(\delta^{13} \mathrm{C}\right)$ isotope values, they can provide a better understanding of diets over longer and potentially more ecologically relevant timescales. This is because stable isotopes reflect the actual assimilation of organic matter over time into consumer 
tissue rather than merely its consumption (Gearing, 1991; Hesslein et al., 1993).

Stable isotope analysis has been successfully applied to analyse the diets, feeding patterns, food web structure and energy flow in fish species of the Lake Victoria basin (Campbell et al., 2003; Mbabazi et al., 2004; Ojwang et al., 2004; Schwartz et al., 2006; Ojwang et al., 2007; Ojwang et al., 2010; Poste et al., 2012). However, these studies were all based on material collected after the mid-1990s and covered relatively short time scales. Nothing is known about the degree to which stable isotope values differ among the haplochromine trophic groups and species before and after the environmental changes that occurred during the 1980s in Lake Victoria. Moreover, except for one recent study (van Rijssel et al., 2016), no attempts have been made to apply stable isotope techniques on preserved museum specimens of haplochromines from Lake Victoria. In general, museum specimens are often preserved in formalin, ethanol, or a combination of both where the fishes are preserved initially in formalin and later transferred to ethanol, which we refer to as "formalin-ethanol preservation". Directional shifts induced by formalin and ethanol preservation of fish have been reported in previous studies (Arrington and Winemiller, 2002; Sarakinos et al., 2002; Kelly et al., 2006; Lau et al., 2012; Gonzalez-Bergonzoni et al., 2015). These studies showed that formalin-ethanol preservation in fish usually depletes $\delta^{13} \mathrm{C}$ and does not change or increases $\delta^{15} \mathrm{~N}$ values. However, the effects of formalin-ethanol preservation can be species specific and preservation effects can also be inconsistent between taxa (Arrington \& Winemiller, 2002; Sarakinos et al., 2002; Kelly et al., 2006; Lau et al., 2012; Gonzalez-Bergonzoni et al., 2015), which is why we tested for preservation effects among trophic groups and species.

This study uses formalin-ethanol-preserved haplochromine specimens collected from the Mwanza Gulf (Tanzania) to answer the following questions: (1) what is the impact of formalin-ethanol preservation on $\delta^{13} \mathrm{C}$ and $\delta^{15} \mathrm{~N}$ values, (2) are there significant differences in stable isotope values between trophic groups and their species within the historic and contemporary ecosystems, and (3) are there differences in stable isotopes of fishes from the historic and contemporary ecosystems, and if so, can they be interpreted in relation to observed shifts in foraging behaviour and environmental change?
Concerning the first question, we expected decreased $\delta^{13} \mathrm{C}$ values and increased or similar $\delta^{15} \mathrm{~N}$ values for formalin-ethanol-preserved samples based on the findings of previous studies. Concerning the second and third question, we expected that differences in stable isotopes between and within trophic groups would reflect changes in diet known from analysis of stomach and gut contents. However, such interpretation must also recognize that some isotopic changes can be related to changes in the environment affecting isotopic values of phytoplankton at the base of the food web. Over the time period sampled in this study, there were substantial changes in the productivity, abundance and composition of phytoplankton, especially in the inshore regions of Lake Victoria in Uganda (Mugidde, 1992; Hecky, 1993; Kling et al., 2001; Hecky et al., 2010). Phytoplankton biomass increased five- to sixfold and became dominated by cyanobacterial filamentous $\mathrm{N}$ fixers such as Anabaena, as well as cyanobacteria that do not fix nitrogen such as colonial Microcystis. There was also a profound species shift in the diatoms from heavily silicified Aulacoseira to thinly silicified Nitzschia as dissolved silica concentrations plummeted in response to the eutrophication of the lake (Hecky, 1993; Kling et al., 2001; Stager et al., 2009). These changes were accompanied by an increase of up to $2 \%$ in (Suess corrected) $\delta^{13} \mathrm{C}$ values for organic matter deposited in inshore areas of the lake (Hecky et al., 2010). In other words, the lake became more productive and phytoplankton demand for $\mathrm{CO}_{2}$ rose relative to available atmospheric $\mathrm{CO}_{2}$. The increase in $\delta^{13} \mathrm{C}$ values would be expected as the increased phytoplankton biomass raised the demand for $\mathrm{CO}_{2}$ and reduced isotopic fractionation (Hecky \& Hesslein, 1995). In fact, $\delta^{13} \mathrm{C}$ values of phytoplankton, which is expected to dominate the particulate matter in tropical productive lakes (Poste et al., 2015), was found to be strongly positively correlated with chlorophyll across a number of East African lakes (Poste et al., 2013). The observed variation in phytoplankton across these lakes is likely due to their varying trophic states (Campbell et al., 2006; Poste et al., 2013).

It is very likely that similar changes in the basal isotopic values occurred in the Mwanza Gulf, which also experienced an increased phytoplankton biomass (Witte et al., 1992a; Cornelissen et al., 2014). Therefore, we expect that consumers in this area would reflect this change at the base of the food web and shift 
to higher $\delta^{13} \mathrm{C}$ values. In contrast, sedimentary $\delta^{15} \mathrm{~N}$ values did not change substantially in the organic matter of the inshore areas of the lake (R. Hecky, unpubl. data), and so any shift of $\delta^{15} \mathrm{~N}$ values in consumers is most likely reflecting a change in the diet.

\section{Methods}

Study area and periods

Haplochromines were caught in the northern part of the Mwanza Gulf between Nyamatala Island and Hippo Island (Fig. 1) in 1977-1982 (historic ecosystem) and 2005-2007 (contemporary ecosystem). Most samples were collected at seven stations (B, E, F, G, H, I, J) on a transect crossing the Mwanza Gulf from Butimba to Kissenda Bay (Fig. 1) which has been sampled repeatedly over several decades (Witte et al., 2007). Except for the littoral station B (4-6 m deep), which has a sand bottom, all other stations have a soft muddy bottom and depths ranging from 5.5 to $13 \mathrm{~m}$. Additional samples were collected in the sublittoral area (6-18 m deep), north and south of the transect between Nyamatala and Hippo Island.

Fish sampling and sample preparation

Haplochromine species were collected by trawling (bottom and surface) and gillnetting. After each haul, the specimens were stored on ice and individuals were assigned to species and trophic group in the laboratory. Specimens collected between 1977 and 1982 were stored at the Naturalis Biodiversity Center, Leiden. They were initially preserved in formaldehyde $(4 \%$ solution) and afterwards transferred to $70 \%$ ethanol. The preservation time varied from several weeks to several years. The standard length (SL) of each specimen was measured. For the stable isotope analysis, a part of the epaxial muscle (dorsal to the lateral line) was dissected and the skin was removed from the sample.

For the samples collected in 2005 and 2007, only muscle tissue from one side was preserved in formaldehyde and later transferred to $70 \%$ ethanol. This preservation treatment was meant to replicate the preservation procedures that have been applied to museum specimens. In this way, materials collected in
2005 and 2007 became comparable with the museum material in terms of preservation treatment. Although the duration of preservation in formaldehyde and ethanol was shorter (several weeks to a year), so far, studies on long-term preservation effects on fish stable isotopes showed that these are independent of time (Ponsard \& Amlou, 1999; Kaehler \& Pakhomov, 2001; Ogawa et al., 2001; Sarakinos et al., 2002; Sweeting et al., 2004) which we assume is also the case for the cichlids used in this study. The muscles from the other side of the fish collected in 2007 (unpreserved) were oven-dried at $60^{\circ} \mathrm{C}$ for $24-48 \mathrm{~h}$ and stored in vials before being transported to the Environmental Isotope Laboratory, University of Waterloo, Canada for analysis.

Trophic groups/species studied

The trophic group classification used in this paper corresponds with that based on morphological features of different trophic groups. This classification was confirmed through stomach and gut content analyses as presented by Seehausen (1996) and Witte and van Oijen (1990). The studied zooplanktivorous species were Haplochromis (Yssichromis) pyrrhocephalus Witte \& Witte-Maas 1987, Haplochromis (Yssichromis) laparogramma Greenwood \& Gee 1969 and Haplochromis tanaos van Oijen \& Witte, 1996 which were identified in catches before and after the environmental changes in the lake. The detritivores comprised Haplochromis (Enterochromis) cinctus Greenwood \& Gee 1969, Haplochromis (Enterochromis) coprologus Niemantsverdriet \& Witte 2010 from the historic ecosystem, and Haplochromis (Enterochromis) 'paropius-like' from the contemporary ecosystem. It is uncertain whether $H$. 'paropiuslike' is conspecific with $H$. (Enterochromis) paropius Greenwood \& Gee 1969 caught in the northern part of the lake in the past. The only confirmed phytoplanktivorous species we analysed was Haplochromis bwathondii Niemantsverdriet \& Witte 2010; however, this species was only caught in the historic ecosystem.

Before the environmental changes, the detritivorous trophic group in the northern part of the Mwanza Gulf comprised several morphologically and ecologically similar species (mainly differing in depth distribution) with a curved dorsal head profile. In this trophic group, sexually active males could be easily identified, but females and non-sexually active 


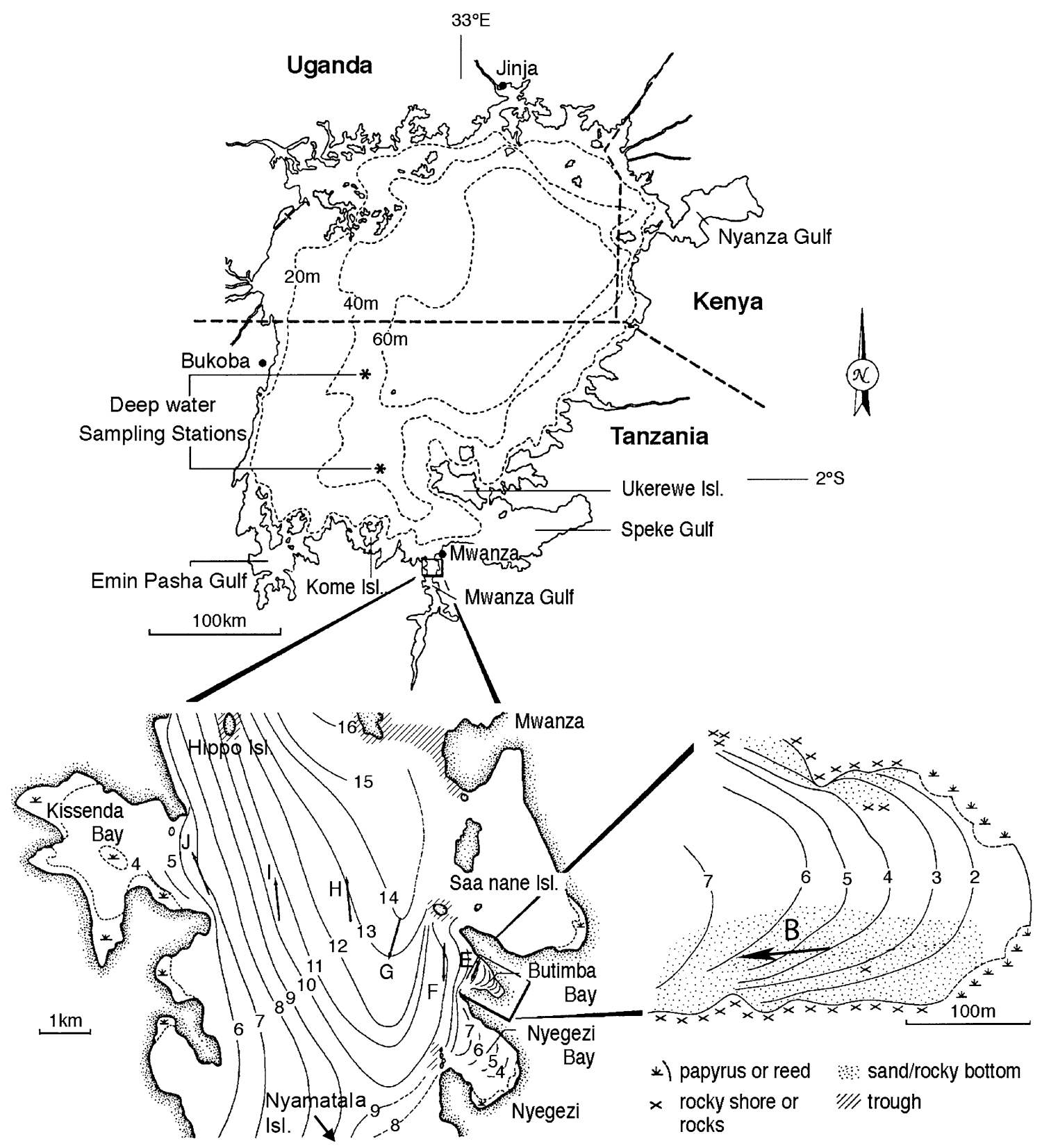

Fig. 1 Lake Victoria showing the sampled stations in the northern part of Mwanza Gulf

(without clear nuptial colouration) males were difficult to identify (de Zeeuw et al., 2010). For that reason, these species were pooled as the "curved head group" in earlier ecological studies (Goldschmidt et al., 1993). The three most common species of this group were Haplochromis cinctus, Haplochromis (Enterochromis) antleter Mietes \& Witte 2010 and Haplochromis (Enterochromis) katunzii ter Huurne
$\&$ Witte 2010. After the recovery of this group in the contemporary ecosystem, specific identification (even of sexually active males) became more difficult due to changes in nuptial colouration and morphology that may have resulted from hybridization (Seehausen et al., 1997a; de Zeeuw et al., 2010). However, based on general morphological features, specimens could still be identified as belonging to the curved head 
group. The curved head group from the contemporary ecosystem comprised individuals that showed features of the three above-mentioned species. From this group, only two individuals could be identified as $H$. cinctus with some certainty.

The stable isotope values of two individuals of the curved head group were outliers resulting in a nonnormal distribution of both $\delta^{13} \mathrm{C}$ and $\delta^{15} \mathrm{~N}$ values. The effect of outlier exclusion was explored by comparison of statistical outputs of the one-way ANOVA performed on the dataset with and without outliers. To avoid discrepancy between statistical analyses (parametric vs. non-parametric tests), we assumed a normal distribution for the group with outliers. Results of the dataset with outliers deviated slightly from the dataset without outliers. Although $P$ values of the one-way ANOVA on both stable isotope values differed, relative differences between species remained the same. Hence, although there are some slight interspecific differences between datasets with and without outliers, inclusion of the two outliers did not affect isotopic differences in time between detritivorous populations, nor our major conclusions (see below).

Stable isotope analysis

A small amount of fish tissue was freeze-dried and ground into fine powder for $\delta^{15} \mathrm{~N}$ and $\delta^{13} \mathrm{C}$ value analyses using a Micromass VG-Isochrom continuous flow isotope ratio mass spectrometer (CF-IRMS). Stable isotope data are presented in delta notation $(\delta)$, which represents the difference (\%o, or parts per thousand) between the isotopic ratio of the sample and the standard, and is calculated as

$$
\begin{aligned}
\delta^{13} \mathrm{C} \text { or } \delta^{15} \mathrm{~N}= & \left(\mathrm{R}_{\text {sample }}-\mathrm{R}_{\text {standard }}\right) /\left(\mathbf{R}_{\text {standard }}\right) \\
& \times 1000,
\end{aligned}
$$

where $\mathrm{R}={ }^{13} \mathrm{CO}_{2} /{ }^{12} \mathrm{CO}_{2}$ for $\delta^{13} \mathrm{C}$ or $\mathrm{R}={ }^{15} \mathrm{~N}_{2} /{ }^{14} \mathrm{~N}_{2}$ for $\delta^{15} \mathrm{~N}$ and where PeeDee belemnite and nitrogen in ambient air are used as standards for $\delta^{13} \mathrm{C}$ and $\delta^{15} \mathrm{~N}$, respectively.

Working standards used to determine inter- and intrarun variation and accuracy of the results included the International Atomic Energy Agency (IAEA) standards CH6 $\left(\delta^{13} \mathrm{C}=-10.4 \%\right), \mathrm{N} 1 \quad\left(\delta^{15} \mathrm{~N}=0.36 \%\right)$ and $\mathrm{N} 2\left(\delta^{15} \mathrm{~N}=20.3 \%\right)$, and the in-house standards: EIL-70 (powdered lipid-extracted Lake Ontario walleye; $\delta^{13} \mathrm{C}=-19.34 \%$ o, $\delta^{15} \mathrm{~N}=16.45 \%$ ) and
EIL-72 (powdered Whatman cellulose fibre; $\delta^{13} \mathrm{C}=-25.4 \%$ ). The food web structure was graphically represented by plotting $\delta^{15} \mathrm{~N}$ against $\delta^{13} \mathrm{C}$ values for all fish.

Over the past 30 years, $\mathrm{CO}_{2}$ levels containing the low natural concentrations of $\delta^{13} \mathrm{C}$ values in the atmosphere have risen over 20\% (Francey et al., 1999) due to deforestation and fossil fuel burning. This change of atmospheric carbon isotopic composition due to anthropogenic effects is also known as the Suess effect (Keeling, 1979). The Suess effect increases as the present day is approached (Verburg, 2007), and so it is necessary to apply a Suess correction (from Verburg, 2007) to the $\delta^{13} \mathrm{C}$ values of a sample according to the following formula:

$$
\begin{aligned}
& 7.7738118 * 10^{-16} * \mathrm{Y}^{6}-1.2222044 * 10^{-11} * \mathrm{Y}^{5} \\
& +7.1612441 * 10^{-8} * \mathrm{Y}^{4}-2.1017147 * 10^{-4} \\
& * \mathrm{Y}^{3}+3.3316112 * 10^{-1} * \mathrm{Y}^{2}-273.715025 \\
& * \mathrm{Y}+91703.261,
\end{aligned}
$$

with $\mathrm{Y}$ as year of collection since 1700 , as recommended by Verburg (2007) to account for changes in fish isotopic composition due to Suess effect alone and to allow comparison of fish specimens collected decades apart. For this study, the Suess correction was applied by subtracting the average correction for the years 1977-1982 from the correction for 2005 and 2007. Hence, the $\delta^{13} \mathrm{C}$ values of samples caught in 2005 and 2007 were Suess-corrected with addition of 0.8 and $0.88 \%$, respectively, in order to account for the declining value of atmospheric $\delta^{13} \mathrm{C}$ values.

\section{Data analysis}

\section{Effects of preservation}

All fish species ( $H$. 'paropius-like', $H$. cinctus, $H$. pyrrhocephalus, H. tanaos, H. laparogramma) collected in 2007 (contemporary ecosystem) were included to test for the overall differences in stable isotope values of $\delta^{13} \mathrm{C}$ and $\delta^{15} \mathrm{~N}$ between preserved and dried samples from the same individuals. The $\delta^{15} \mathrm{~N}$ values of the dried and preserved muscle tissue samples were tested with a paired student $t$ test; the $\delta^{13} \mathrm{C}$ values were not normally distributed (ShapiroWilk test) and therefore tested with a paired Wilcoxon test. 


\section{Effects of fish body size}

Historic H. pyrrhocephalus had a significant negative Pearson correlation between $\delta^{13} \mathrm{C}$ values and standard length, SL $(P=0.014$; Table 1$)$. A significant positive Pearson correlation with SL for $\delta^{15} \mathrm{~N}$ values was found for historic $H$. pyrrhocephalus specimens as well as for $H$. 'paropius-like' specimens $(P<0.05$; Table 1). We performed a linear regression on these three groups and used the residuals for further analysis to correct for the effect of SL on stable isotopes. Residuals of non-correlated stable isotopes were calculated manually by subtraction of the average stable isotope values from the raw data. All residuals were normally distributed (Shapiro-Wilk test, $P>0.05$ ). Additionally, we tested with a one-way ANOVA whether historic and contemporary species/ trophic groups decreased in SL compared to the same species/trophic groups of the historic ecosystem. Only $H$. pyrrhocephalus from the contemporary ecosystem showed a significant decrease of SL compared to $H$. pyrrhocephalus of the historic ecosystem (ANOVA, $\mathrm{df}=16, t=8.61, P<0.001)$.

\section{Inter- and intraspecific differences}

A one-way ANOVA was performed on both residuals (linear regression and manually calculated) to test for interspecific differences in the historic period. A pairwise Wilcoxon signed rank test was used for

Table 1 Pearson correlations per species and period between $\delta^{13} \mathrm{C}, \delta^{15} \mathrm{~N}$ and SL

\begin{tabular}{|c|c|c|c|c|c|}
\hline & \multirow[t]{2}{*}{$n$} & \multicolumn{2}{|l|}{$\delta^{13} \mathrm{C}$} & \multicolumn{2}{|l|}{$\delta^{15} \mathrm{~N}$} \\
\hline & & $R$ & $P$ & $R$ & $P$ \\
\hline \multicolumn{6}{|l|}{ Historic } \\
\hline H. bwathondii & 10 & 0.265 & 0.46 & 0.291 & 0.415 \\
\hline H. cinctus & 10 & 0.301 & 0.399 & -0.366 & 0.299 \\
\hline H. coprologus & 10 & -0.11 & 0.976 & 0.371 & 0.291 \\
\hline H. pyrrhocephalus & 10 & -0.741 & 0.014 & 0.705 & $\mathbf{0 . 0 2 3}$ \\
\hline H. tanaos & 5 & 0.324 & 0.595 & 0.4 & 0.505 \\
\hline \multicolumn{6}{|l|}{ Contemporary } \\
\hline Curved head group & 12 & 0.045 & 0.879 & -0.229 & 0.43 \\
\hline$H$. 'paropius-like' & 15 & -0.303 & 0.273 & 0.611 & 0.015 \\
\hline H. pyrrhocephalus & 9 & 0.395 & 0.292 & -0.340 & 0.370 \\
\hline H. tanaos & 6 & 0.417 & 0.411 & -0.143 & 0.787 \\
\hline
\end{tabular}

Significant values are depicted in bold interspecific differences in the contemporary period and for intraspecific differences among periods because of the non-normal distribution of the curved head group. To test whether interspecific clustering of stable isotope values differed between the historic and contemporary populations, we calculated the Bhattacharyya distance ( $\mathrm{Bd}$, which takes into account different standard deviations between clusters) between each species cluster within a period using the bhattacharyya.dist function from the $\mathrm{R}$ package 'fpc' (R development Core Team, 2016). Significance of Bds was tested with a Hotelling's T-squared test in R. A sequential Bonferroni correction was used to adjust the $P$ values. Although the two specimens of $H$. laparogramma were shown in the figures, they were not included in the statistical analysis due to their low sample size. All statistical tests were performed with SPSS 20.0 for Windows unless mentioned otherwise.

\section{Results}

\section{Effects of preservation}

The dried and the formalin-ethanol-preserved samples of the same individual showed significant differences in their stable isotope values (Table S1 in Electronic Supplementary Material). This is illustrated by the preserved and dried samples of $H$. 'paropius-like', which show differences that are generally in the same direction (Fig. 2). The preserved samples of all species combined had significantly lower $\delta^{13} \mathrm{C}$ values than the dried samples (preserved $18.88 \% \pm 2.71$, dried $18.22 \%$ o \pm .78; paired Wilcoxon Signed Rank Test, $Z=-2.98, P=0.003$ ), and significantly higher $\delta^{15} \mathrm{~N}$ values than the dried samples (preserved 9.07\% \pm 1.59 , dried 8.73\%o \pm 1.52 ; paired Student $T$ Test, $\mathrm{df}=32, t=-2.31, P=0.028)$. Although the differences were significant, the magnitudes are small relative to the changes observed among species and over time in the same/similar species that we discuss below.

Interspecific differences

\section{Historic populations}

The stable isotope analysis of the historic ecosystem species resulted in a distinct clustering of the species 
Fig. 2 Isotopic composition of dried and preserved samples of $H$. 'paropius-like'.

a Represents $\delta^{13} \mathrm{C}$ values and $\mathbf{b}$ represents $\delta^{15} \mathrm{~N}$ values for each specimen

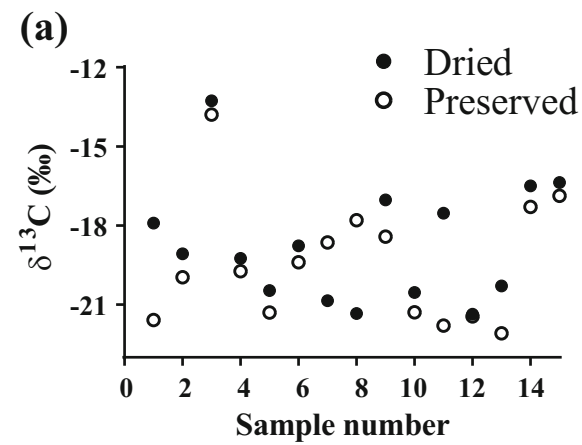

(b)

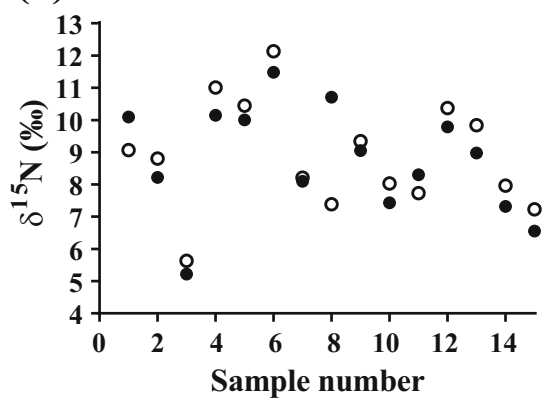

(Fig. 3a; Table 2). Except for stable isotope clusters of H. coprologus and H. tanaos, all other nine clusters were significantly different from each other with a mean Bd of 5.59 (Table 2). All the historic species differed significantly from each other in $\delta^{13} \mathrm{C}$ values $\left(P<0.01\right.$; Table 3), except for $\delta^{13} \mathrm{C}$ values of the detritivore $H$. coprologus and the zooplanktivore $H$. tanaos and those of the phytoplanktivore H. bwathondii and the zooplanktivore $H$. pyrrhocephalus. The zooplanktivores, together with the detritivore $H$. coprologus, did not differ significantly from each other but did show the highest $\delta^{15} \mathrm{~N}$ values compared to $H$. bwathondii and $H$. cinctus $(P<0.001$; Table 3 ; Fig. 3a). The detritivore $H$. cinctus showed the lowest $\delta^{13} \mathrm{C}$ and $\delta^{15} \mathrm{~N}$ values $(P<0.001$; Table 3; Fig. 3a). The phytoplanktivore $H$. bwathondii showed the highest $\delta^{13} \mathrm{C}$ values $(P<0.01$; Table 3 ; Fig. 3a, although not significantly different from $H$. pyrrhocephalus), and showed intermediate $\delta^{15} \mathrm{~N}$ values compared to the other four species. Of the two
Fig. 3 Isotopic composition of different species of different trophic groups. Filled symbols represent historic species, unfilled symbols represent contemporary species. a Historic species; b contemporary species; c historic and contemporary ecosystem curved head group (including $H$. cinctus); d Historic and contemporary system zooplanktivores

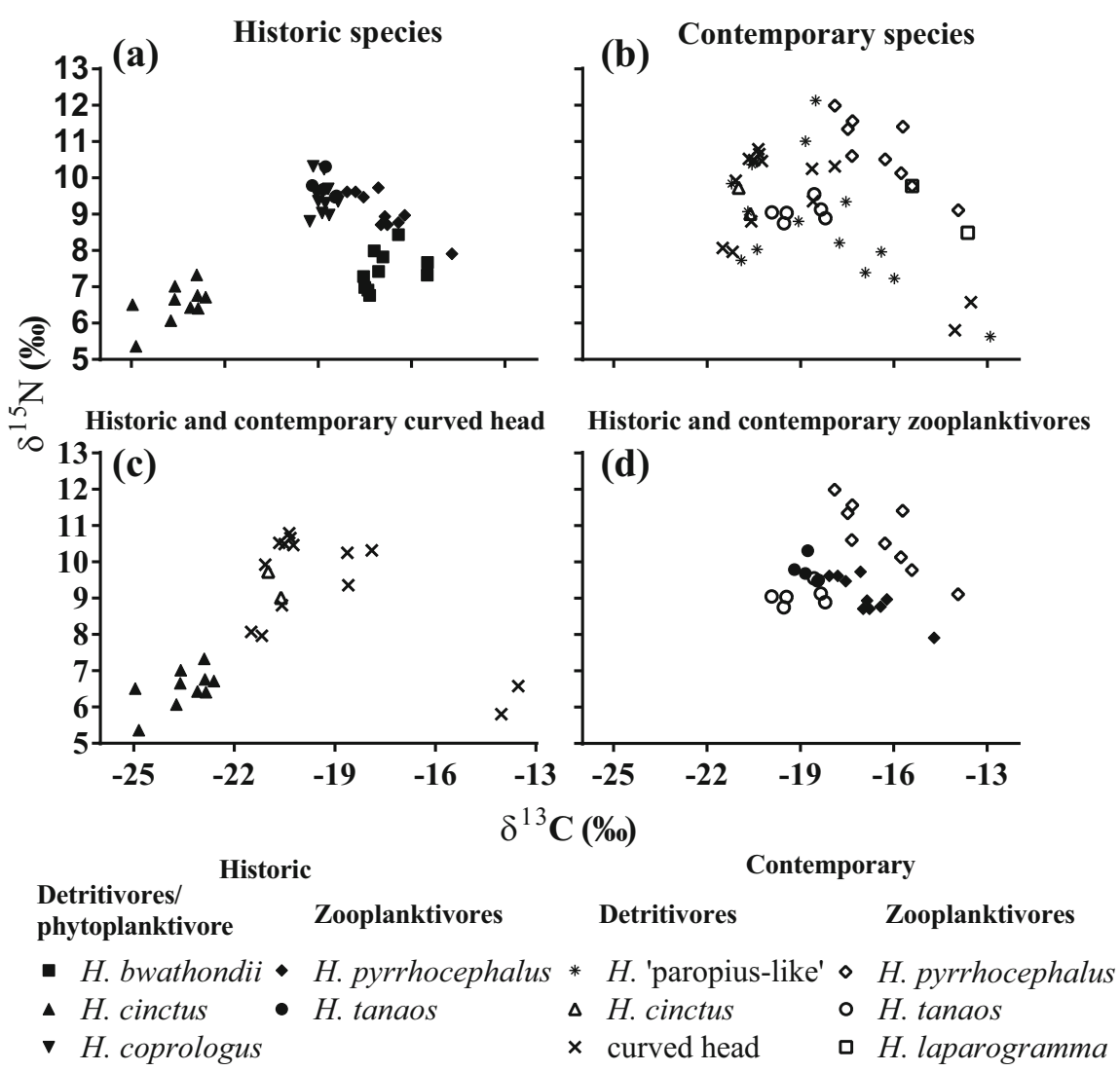


Table 2 Bhattacharyya distances (Bd) between species clusters of stable isotope values of the historic and contemporary populations

\begin{tabular}{|c|c|c|c|}
\hline Species cluster & Species cluster & $\mathrm{Bd}$ & $P$ value \\
\hline \multicolumn{4}{|l|}{ Historic } \\
\hline H. bwathondii & H. cinctus & 9.64 & $<0.001$ \\
\hline H. bwathondii & H. bwathondii & 4.77 & $<0.001$ \\
\hline H. bwathondii & H. pyrrhocephalus & 1.51 & $<0.001$ \\
\hline H. bwathondii & H. tanaos & 6.14 & $<0.001$ \\
\hline H. cinctus & H. bwathondii & 8.52 & $<0.001$ \\
\hline H. cinctus & H. pyrrhocephalus & 12.24 & $<0.001$ \\
\hline H. cinctus & H. tanaos & 10.19 & $<0.001$ \\
\hline H. coprologus & H. pyrrhocephalus & 1.56 & $<0.001$ \\
\hline H. coprologus & H. tanaos & 0.15 & 0.496 \\
\hline \multirow[t]{2}{*}{ H. pyrrhocephalus } & H. tanaos & 1.20 & 0.004 \\
\hline & Average & 5.59 & \\
\hline \multicolumn{4}{|l|}{ Contemporary } \\
\hline Curved head group & H. 'paropius-like' & 0.40 & 0.056 \\
\hline Curved head group & H. pyrrhocephalus & 2.16 & $<0.001$ \\
\hline Curved head group & H. tanaos & 0.87 & 0.007 \\
\hline$H$. 'paropius-like' & H. pyrrhocephalus & 1.41 & $<0.001$ \\
\hline H. 'paropius-like' & H. tanaos & 0.83 & 0.902 \\
\hline \multirow[t]{2}{*}{ H. pyrrhocephalus } & H. tanaos & 4.85 & $<0.001$ \\
\hline & Average & 1.75 & \\
\hline
\end{tabular}

Significant $P$ values of the Hotelling's T-squared test are depicted in bold

zooplanktivorous species, $H$. pyrrhocephalus showed significantly higher $\delta^{13} \mathrm{C}$ values compared to $H$. tanaos (ANOVA, df $=12, t=4.04, P=0.002$ ).

\section{Contemporary populations}

The analysis showed a clustering by species, but there was more overlap between species than in historic samples, and larger variation in both $\delta^{13} \mathrm{C}$ and $\delta^{15} \mathrm{~N}$ values (Fig. 3b; Table 2). Four out of six species cluster comparisons showed significantly different $\mathrm{Bds}$, with a mean $\mathrm{Bd}$ of 1.75 (Table 2). The stable isotope values of the zooplanktivore $H$. pyrrhocephalus were the only ones that differed from the other three contemporary species (Table 4). Haplochromis pyrrhocephalus showed the highest $\delta^{13} \mathrm{C}$ and $\delta^{15} \mathrm{~N}$ values compared to the other species $(P<0.05$; Table 4). The stable isotope values of the zooplanktivore H. laparogramma showed overlap with those of the H. pyrrhocephalus population (Fig. 3b).

Intraspecific differences between historic and contemporary populations

Curved head populations (which include $H$. cinctus) of the contemporary ecosystem showed significantly higher $\delta^{13} \mathrm{C}$ and $\delta^{15} \mathrm{~N}$ values than $H$. cinctus of the historic ecosystem $(P<0.001$; Fig. $3 c$; Table 5$)$. The $H$. pyrrhocephalus population of the contemporary ecosystem did not differ from the historic population in $\delta^{13} \mathrm{C}$ values but had significantly higher $\delta^{15} \mathrm{~N}$ values (Wilcoxon Signed Rank Test, $Z=-2.87, P=0.004$; Fig. 3d). Historic and contemporary $H$. tanaos populations did not show significant differences in stable isotope values (Fig. 3d; Table 5).
Table 3 Pairwise species comparisons of stable isotope values of species from the historic ecosystem
Significant $P$ values (after sequential Bonferroni correction) of the one-way ANOVA are indicated in bold

\begin{tabular}{|c|c|c|c|c|c|c|}
\hline \multicolumn{2}{|l|}{ Historic populations } & \multicolumn{3}{|c|}{$\delta^{13} \mathrm{C}$} & \multicolumn{2}{|l|}{$\delta^{15} \mathrm{~N}$} \\
\hline Species & Species & $\mathrm{df}$ & $t$ & $P$ value & $t$ & $P$ value \\
\hline H. bwathondii & H. cinctus & 18 & 18.32 & $<0.001$ & 4.03 & 0.001 \\
\hline H. bwathondii & H. bwathondii & 18 & 7.85 & $<0.001$ & -8.91 & $<0.001$ \\
\hline H. bwathondii & H. pyrrhocephalus & 17 & -0.16 & 0.99 & -6.42 & $<0.001$ \\
\hline H. bwathondii & H. tanaos & 13 & 5.16 & $<0.001$ & -9.1 & $<0.001$ \\
\hline H. cinctus & H. bwathondii & 18 & -16.45 & $<0.001$ & -12.92 & $<0.001$ \\
\hline H. cinctus & H. pyrrhocephalus & 17 & -15.65 & $<0.001$ & -10.03 & $<0.001$ \\
\hline H. cinctus & H. tanaos & 13 & -12.01 & $<0.001$ & -12.54 & $<0.001$ \\
\hline H. coprologus & H. pyrrhocephalus & 17 & -6.2 & $<0.001$ & 1.58 & 0.13 \\
\hline H. coprologus & H. tanaos & 13 & -0.97 & 0.35 & -1.18 & 0.26 \\
\hline H. pyrrhocephalus & H. tanaos & 12 & 4.04 & 0.002 & -2.37 & 0.04 \\
\hline
\end{tabular}


Table 4 Pairwise species comparisons of stable isotope values of species from the contemporary ecosystem

\begin{tabular}{|c|c|c|c|c|c|c|c|}
\hline \multicolumn{4}{|c|}{ Contemporary populations } & \multicolumn{2}{|l|}{$\delta^{13} \mathrm{C}$} & \multicolumn{2}{|l|}{$\delta^{15} \mathrm{~N}$} \\
\hline Species & $n$ & Species & $n$ & $Z$ & $P$ value & $Z$ & $P$ value \\
\hline Curved head group & 16 & H. 'paropius-like' & 15 & -1.35 & 0.18 & -0.99 & 0.32 \\
\hline Curved head group & 16 & H. pyrrhocephalus & 9 & -3.01 & 0.002 & -2.3 & 0.02 \\
\hline Curved head group & 16 & H. tanaos & 6 & -1.7 & 0.09 & -1.03 & 0.3 \\
\hline H. 'paropius-like' & 15 & H. pyrrhocephalus & 9 & -2.57 & 0.01 & -2.6 & 0.009 \\
\hline H. 'paropius-like' & 15 & H. tanaos & 6 & -0.08 & 0.94 & -0.43 & 0.67 \\
\hline H. pyrrhocephalus & 9 & H. tanaos & 6 & -3.19 & 0.001 & -2.84 & 0.005 \\
\hline
\end{tabular}

Significant $P$ values (after sequential Bonferroni correction) of the Wilcoxon Signed Rank Test are indicated in bold

Table 5 Comparisons of stable isotope values of species from the historic and the contemporary ecosystem

\begin{tabular}{|c|c|c|c|c|c|c|c|}
\hline \multicolumn{2}{|l|}{ Historic } & \multicolumn{2}{|l|}{ Contemporary } & \multicolumn{2}{|l|}{$\delta^{13} \mathrm{C}$} & \multicolumn{2}{|l|}{$\delta^{15} \mathrm{~N}$} \\
\hline Species & $n$ & Species & $n$ & $Z$ & $P$ value & $Z$ & $P$ value \\
\hline H. cinctus & 10 & Curved head group & 16 & -4.22 & $<0.001$ & -3.48 & $<0.001$ \\
\hline H. pyrrhocephalus & 9 & H. pyrrhocephalus & 9 & -0.8 & 0.43 & -2.87 & 0.004 \\
\hline H. tanaos & 5 & H. tanaos & 6 & -0.37 & 0.71 & -1.38 & 0.12 \\
\hline
\end{tabular}

Significant $P$ values of the Wilcoxon Signed Rank Test are indicated in bold

\section{Discussion}

\section{Effects of preservation}

The observed depletion of $\delta^{13} \mathrm{C}$ values in formalinethanol-preserved samples $(0.66 \%$ on average, SD 0.07) may have occurred due to hydrolysis of proteins by formalin (Arrington \& Winemiller, 2002; Sarakinos et al., 2002). The depletion could be also due to uptake of formalin and ethanol into the tissues as both preservatives are carbon-based chemicals with characteristic $\delta^{13} \mathrm{C}$ values. Once preserved samples are immersed, their values may shift towards that of the preservative (Arrington \& Winemiller, 2002; Sarakinos et al., 2002; Kelly et al., 2006; Lau et al., 2012; Gonzalez-Bergonzoni et al., 2015).

Our findings indicate that formalin-ethanol preservation leads to an increase in $\delta^{15} \mathrm{~N}$ values $(0.34 \%$ on average, SD 0.07). The specific mechanism that leads to the observed increase in $\delta^{15} \mathrm{~N}$ values is unknown; however, nitrogen enrichment has also been observed by other studies on preservation effects (Arrington \& Winemiller, 2002; Sarakinos et al., 2002; Kelly et al., 2006; Lau et al., 2012; Gonzalez-Bergonzoni et al., 2015).
Although the preservation effects per species are consistent, this is not always the case on the individual level. Six out of 33 specimen samples tested showed an inconsistent shift (shifts in a different direction compared to the other samples) in either $\delta^{13} \mathrm{C}$ and/or $\delta^{15} \mathrm{~N}$ values (Table S1). Two samples showed inconsistent shifts in both $\delta^{13} \mathrm{C}$ and $\delta^{15} \mathrm{~N}$ values. The inconsistencies do not seem to be species specific. Three out of $24(12.5 \%)$ of the detritivore samples showed inconsistent shifts in either $\delta^{13} \mathrm{C}$ and/or $\delta^{15} \mathrm{~N}$ values, while one out of nine zooplanktivore samples $(11.1 \%)$ showed an inconsistent shift in both $\delta^{13} \mathrm{C}$ and $\delta^{15} \mathrm{~N}$ values. Since the relative number of inconsistent shifts is similar between detritivores and zooplanktivores, we cannot state that the inconsistency and thus preservation effects depend on the trophic level nor species identity and is more likely the result of a methodological inconsistency (e.g. slightly different parts of muscle tissue that were used).

Nevertheless, when we look at the magnitude of the preservation effect $(0.34-0.66 \%)$, the differences found between species and sampling periods are much larger than those found between dried and preserved samples. For instance, the differences in $\delta^{13} \mathrm{C}$ (Suess corrected) and $\delta^{15} \mathrm{~N}$ values between historic and 
contemporary $H$. cinctus populations are $4.1 \%$ and $2.8 \%$, respectively, which is much higher than the above-mentioned differences between dried and preserved samples of the specimens (Figs. 2, 3). Moreover, the formalin-ethanol-preserved historic and contemporary samples used in this study have been preserved in the same way in order to avoid discrepancies in the dataset that could be caused due to different preservation treatments. These observations suggest that formalin-ethanol-preserved Lake Victoria cichlids still provide ecologically meaningful stable isotope data, or at minimum that preservation did not impose a common signal arising from the formalin-ethanol preservative (Table S2). This conclusion is supported by several other studies that used stable isotope analysis on museum specimens to generate retrospective ecological insight (Vander Zanden et al., 2003; Schmidt et al., 2009; Nakazawa et al., 2010).

Interspecific differences in historic populations

Although the specimens from the historic populations were collected in different years and, for $H$. pyrrhocephalus, at different locations in the northern part of the Mwanza Gulf (Table S2, S3), they revealed distinct and well-separated conspecific clusters (Fig. 3; Table 2). Moreover, as expected, the two zooplanktivorous species had higher $\delta^{15} \mathrm{~N}$ values than two of the three detritivorous species.

The distinction along the $\delta^{13} \mathrm{C}$ and $\delta^{15} \mathrm{~N}$ values axes can partly be explained by the different diets of the species. The bottom dwelling detritivore $H$. cinctus, which mainly fed on detritus and phytoplankton and which included some copepods and midge larvae in its diet (Goldschmidt et al., 1993), had the lowest $\delta^{13} \mathrm{C}$ and $\delta^{15} \mathrm{~N}$ values. Unexpectedly, the other detritivore, $H$. coprologus, had the highest $\delta^{15} \mathrm{~N}$ values. Haplochromis coprologus fed mainly on detritus and phytoplankton during the day, but also included some copepods in its diet (Goldschmidt et al., 1993). Apart from detritus, $H$. coprologus also fed on the diatom Aulacoseira, especially at night, when the fish occurred a little higher up in the water column (Goldschmidt et al., 1993). Two possibilities can be offered for the higher $\delta^{15} \mathrm{~N}$ values in $H$. coprologus compared to the other detritivores. It is possible that Aulacoseira had higher $\delta^{15} \mathrm{~N}$ values than detritus, or $H$. coprologus had a more mixed diet that included zooplankton in significant amounts. Different species of phytoplankton can exhibit different $\delta^{15} \mathrm{~N}$ values due to utilization of different inorganic $\mathrm{N}$ sources, and they can also differ from detritus (Vuorio et al., 2006). However, the phytoplanktivore $H$. bwathondii which might be expected to incorporate substantial amounts of Aulacoseira, did not exhibit the enriched $\delta^{15} \mathrm{~N}$ values of $H$. coprologus, and this would argue against the enriched Aulacoseira explanation.

There was considerable overlap of $\delta^{13} \mathrm{C}$ and $\delta^{15} \mathrm{~N}$ values between the detritivore, $H$. coprologus and the zooplanktivore H. tanaos (Fig. 3a, b) which may be linked to the habitat overlap between these two species during a part of their life cycle. Juveniles of $H$. coprologus occurred in the same sheltered bays (e.g. Butimba Bay), and fed mainly on zooplankton (F. Witte, unpubl. data) like $H$. tanaos, which in the historic ecosystem used to occur in this habitat throughout its life (Goldschmidt et al., 1993; van Oijen \& Witte, 1996). A more zooplanktivorous diet by $H$. coprologus juveniles might have contributed to their high $\delta^{15} \mathrm{~N}$ values.

The pelagic phytoplanktivore $H$. bwathondii had relatively high $\delta^{15} \mathrm{~N}$ values compared to $H$. cinctus, and had the highest $\delta^{13} \mathrm{C}$ values of all species (possibly due to its phytoplanktivorous habits). All aquatic plants have a stagnant boundary layer that restricts the rate of $\mathrm{CO}_{2}$ or $\mathrm{HCO}_{3}{ }^{-}$diffusion and thus limits the rate of photosynthesis (France, 1995; Smith \& Walker, 1980). In effect, this boundary layer makes the carbon pool finite and can lead to instantaneous C-limitation which reduces isotopic discrimination and results increased $\delta^{13} \mathrm{C}$ values (Smith \& Walker, 1980; Keeley \& Sandquist, 1992). Haplochromis bwathondii fed mainly on cyanophytes (Microcystis and Anabaena) and diatoms such as Aulacoseira and occasionally Nitzschia. Larger phytoplankton such as colonial or filamentous cyanobacteria species, like the ones that contribute to the diet of $H$. bwathondii, often exhibit higher $\delta^{13} \mathrm{C}$ values (Vuorio et al., 2006) because they are more subject to these boundary layer effects (France, 1995; Hecky \& Hesslein, 1995). At night, $H$. bwathondii also consumed considerable amounts of adult insects and Chaoborus larvae and pupae as well as some copepods (Goldschmidt et al., 1993). The uptake of insects and zooplankton would also contribute to the relatively higher $\delta^{15} \mathrm{~N}$ values compared to $H$. cinctus; however, $\delta^{15} \mathrm{~N}$ values were much lower than those of $H$. coprologus and the zooplanktivorous 
species (Fig. 3a). Some aquatic insects do have generally low $\delta^{15} \mathrm{~N}$ values (Campbell et al., 2003) which could explain the relatively lower $\delta^{15} \mathrm{~N}$ values compared to the zooplanktivores. Unfortunately, we lack stable isotope values of prey items caught at the same time and location to confirm this.

The higher $\delta^{15} \mathrm{~N}$ values of the zooplanktivores $H$. pyrrhocephalus and H. tanaos are consistent with their diet, mainly cyclopoid/calanoid copepods and cladocerans, respectively (van Oijen \& Witte, 1996; Goldschmidt, 1989). The higher $\delta^{13} \mathrm{C}$ values observed in $H$. pyrrhocephalus compared to those in $H$. tanaos might result from a difference in habitat usage of both species or the difference in diet. Haplochromis tanaos was collected from the shallow Butimba bay, while $H$. pyrrhocephalus was mainly caught in open water (Table S3). This habitat difference might have resulted in different $\delta^{13} \mathrm{C}$ values at the base of the food web which are reflected in different $\delta^{13} \mathrm{C}$ values of the cichlids. However, this difference is actually the opposite of what one would expect, based on the geographic variation in $\delta^{13} \mathrm{C}$ values in Lake Victoria where inshore, shallow habitats had higher $\delta^{13} \mathrm{C}$ values in particulate organic matter (Hecky et al., 2010; van Rijssel et al., 2016, see below). Therefore, it is more likely that the different diets of $H$. pyrrhocephalus (cyclopoid/calanoid copepods and chironomid larvae) and H. tanaos (cladocerans and insects) are responsible for the difference in $\delta^{13} \mathrm{C}$ values (Goldschmidt 1989; van Oijen \& Witte, 1996).

\section{Interspecific differences contemporary populations}

The clustering of the stable isotopes values of the contemporary populations showed less species distinction than the clustering of the historic populations (Table 2; Fig. 3a, b). The Bds between clusters of stable isotope values of the contemporary populations were only significant in 4 out of 6 species cluster comparisons (compared to 9 out of 10 for the historic species clusters) and had an average Bd of only 1.75 (compared to 5.59 for the historic species clusters). This stable isotope overlap confirms the findings of earlier diet studies of these species, reporting a dietary shift to a more carnivorous diet, resulting in more overlap between detritivores and zooplanktivores (Kishe-Machumu et al., 2008; Kishe-Machumu, 2012). After their resurgence, both trophic groups included zooplankton, midge larvae, insects, molluscs and shrimps in their diet (van Oijen \& Witte, 1996; Katunzi et al., 2003; Kishe-Machumu et al., 2008; Kishe-Machumu, 2012; van Rijssel et al., 2015). The $\delta^{15} \mathrm{~N}$ values of the curved head group and $H$. 'paropius-like' displayed a very broad range. The broad range of the latter species might be explained by the large variation in SL in our samples (Table S3), as smaller fish might have a different diet than larger fish. Diet analysis revealed that in the contemporary curved head population, prey diversity was higher than in the pooled historic detritivores $H$. coprologus and four curved head species (Kishe-Machumu et al., 2008). However, it should be noted that prey diversity does not necessarily explain the range of $\delta^{15} \mathrm{~N}$ values, as some prey types have similar values while others may differ greatly. For example, zooplankton are generally substantially enriched in their $\delta^{15} \mathrm{~N}$ values, while aquatic insects can be rather low in $\delta^{15} \mathrm{~N}$ values (Campbell et al., 2003).

We noticed that the curved head group of the contemporary system appears to exhibit a depth effect with higher $\delta^{13} \mathrm{C}$ and lower $\delta^{15} \mathrm{~N}$ values of specimens caught at the shallowest station on the transect, $\mathrm{J}$ (Figs. 1, 4). The shallow inshore waters of Lake Victoria have shown the greatest increases in algal biomass compared to the offshore waters. In addition, in the contemporary ecosystem of the lake, chlorophyll and particulate $\mathrm{C}$ and $\mathrm{N}$ concentrations are much higher than in the past and the $\delta 13 \mathrm{C}$ value of particulate matter is much heavier in shallow waters (Hecky et al., 2010). Water depth imposes strong isotopic gradients because algal production is generally light limited by self-shading in the contemporary ecosystem (Silsbe et al., 2006). As a consequence, $\delta^{13} \mathrm{C}$ values are higher inshore and fall as the bottom depths increase. Conversely, $\delta^{15} \mathrm{~N}$ values are lower inshore because $\mathrm{N}$ fixing cyanobacteria dominate the higher algal biomass and $\delta^{15} \mathrm{~N}$ values increase as depth increases and $\mathrm{N}$ fixation becomes increasingly light limited (Mugidde et al., 2003).

This likely explains the observed depth effect for the curved head group (Table 6; Fig. 4). The zooplanktivores $H$. pyrrhocephalus and $H$. laparogramma caught at station $\mathbf{J}$ also showed a similar pattern in their stable isotope composition compared to specimens caught in deeper waters (Table 6). This depth effect in the contemporary lake ecosystem indicates that populations of these haplochromines species can be quite stenotopic. It is commonly accepted that 
Fig. 4 Variation in depth of Suess-corrected $\delta^{13} \mathrm{C}$ (a) and $\delta^{15} \mathrm{~N}$ values (b) of the curved head group along the 5-km research transect. Shallower stations tend to show higher $\delta^{13} \mathrm{C}$ and lower $\delta^{15} \mathrm{~N}$ values compared to deeper stations
Curved head group

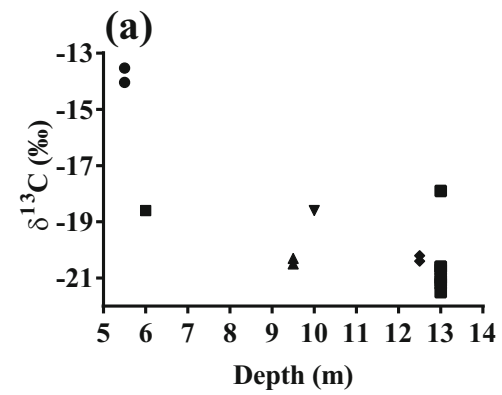

many cichlid species are restricted by bottom types, depths or parts of the water column but an almost complete lack of dispersal between stations required to explain these data have not been reported for these demersal species (Witte, 1981; Witte et al., 2007) until very recently (van Rijssel et al., 2016). The general effect of depth on the stable isotope values of phytoplankton, which is evident at the whole lake scale (Hecky et al., 2010), seems to be also present at smaller spatial scales within Mwanza Gulf and is expressed in the isotopic values of stenotopic haplochromine species.

\section{Intraspecific differences between historic and contemporary populations}

The higher $\delta^{15} \mathrm{~N}$ values of the contemporary curved head population compared to the historic population concurred with the diet change towards more insects and zooplankton (Kishe-Machumu et al., 2008). The higher $\delta^{13} \mathrm{C}$ values in the curved head population of the contemporary ecosystem agrees with the hypothetical changes at the base of food web, leading to a shift to higher $\delta^{13} \mathrm{C}$ values (Hecky et al., 2010).

The contemporary $H$. pyrrhocephalus population shifted to higher $\delta^{15} \mathrm{~N}$ values probably as a result of the inclusion of larger prey with higher $\delta^{15} \mathrm{~N}$ values such as juvenile fish (Table 7). We found a significant decrease in body size for the contemporary $H$. pyrrhocephalus population compared to the historic population. This decrease can have an effect on their prey consumption and therefore stable isotope values (e.g. by means of gape limitation). However, as the contemporary $H$. pyrrhocephalus population included more larger prey than the historic population (Table 7), we do not think that the size decrease had a major impact on the diet and thus stable isotope values of these fish. The shift in $\delta^{15} \mathrm{~N}$ values of $H$. pyrrhocephalus cannot be explained by changes in the basal $\delta^{15} \mathrm{~N}$ values as the lake has become dominated by cyanobacteria which account for a majority of the new nitrogen in the system due to nitrogen fixation

Table 6 Stable isotope values (Suess corrected) of contemporary ecosystem haplochromine species per station

\begin{tabular}{|c|c|c|c|c|c|c|c|}
\hline Species/station & Signature & $\begin{array}{l}\mathrm{J} \\
5.5 \mathrm{~m}\end{array}$ & $\begin{array}{l}\mathrm{E} \\
6 \mathrm{~m}\end{array}$ & $\begin{array}{l}\mathrm{F} \\
9.5 \mathrm{~m}\end{array}$ & $\begin{array}{l}\mathrm{I} \\
10 \mathrm{~m}\end{array}$ & $\begin{array}{l}\mathrm{H} \\
12.5 \mathrm{~m}\end{array}$ & $\begin{array}{l}\mathrm{G} \\
13 \mathrm{~m}\end{array}$ \\
\hline \multirow[t]{2}{*}{ Curved head group } & $\delta^{13} \mathrm{C}$ & $-13.5,-14.0$ & -18.6 & $-20.5,-20.3$ & -18.6 & $-20.2,-20.4$ & $-20.6(8)$ \\
\hline & $\delta^{15} \mathrm{~N}$ & $6.6,5.8$ & 9.4 & $10.5,10.7$ & 10.3 & $10.5,10.8$ & $9.3(8)$ \\
\hline \multirow[t]{2}{*}{ Haplochromis 'paropius-like' } & $\delta^{13} \mathrm{C}$ & $-19.6(3)$ & $-18.4(6)$ & & & & $-18.1(6)$ \\
\hline & $\delta^{15} \mathrm{~N}$ & $8.3(3)$ & $9.5(6)$ & & & & $8.5(6)$ \\
\hline \multirow[t]{2}{*}{ Haplochromis pyrrhocephalus } & $\delta^{13} \mathrm{C}$ & $-15.8(4)$ & $-17.9,-13.9$ & $-17.4(3)$ & & & \\
\hline & $\delta^{15} \mathrm{~N}$ & $10.4(4)$ & $12.0,9.1$ & $11.2(3)$ & & & \\
\hline \multirow[t]{2}{*}{ Haplochromis laparogramma } & $\delta^{13} \mathrm{C}$ & $-13.6,-15.4$ & & & & & \\
\hline & $\delta^{15} \mathrm{~N}$ & $8.5,9.8$ & & & & & \\
\hline
\end{tabular}

The depth of each station is given. Averaged values are depicted when $n>2$ with the $n$ given in parentheses 
Table 7 Mean volume percentages ( \pm standard deviations) of stomach and gut contents of H. pyrrhocephalus and H. tanaos from before and after the environmental changes

\begin{tabular}{|c|c|c|c|c|}
\hline & \multicolumn{2}{|c|}{ H. pyrrhocephalus } & \multicolumn{2}{|l|}{ H. tanaos } \\
\hline & $\begin{array}{l}n=32 \\
1977-1982^{\mathrm{b}}\end{array}$ & $\begin{array}{l}n=48 \\
2005-2006^{\mathrm{c}}\end{array}$ & $\begin{array}{l}n=47 \\
1977-1981^{\mathrm{d}}\end{array}$ & $\begin{array}{l}n=31 \\
2005-2006^{\mathrm{e}}\end{array}$ \\
\hline Detritus & $4.2 \pm 17.8$ & $4.6 \pm 7.9$ & $2.9 \pm 7.2$ & $4.9 \pm 6.4$ \\
\hline Phytoplankton & $3.6 \pm 9.4$ & $1.1 \pm 2.7$ & $1.4 \pm 7.1$ & 0 \\
\hline Zooplankton $^{\mathrm{a}}$ & $63.9 \pm 30.8$ & $46.9 \pm 33.6$ & $57.1 \pm 39.3$ & $10.7 \pm 21.1$ \\
\hline Ostracods & 0 & $1.7 \pm 5$ & 0 & $7.1 \pm 12.1$ \\
\hline Chironomids & $2.1 \pm 5.9$ & $5.3 \pm 14.4$ & $7.7 \pm 22.8$ & $30.5 \pm 33$ \\
\hline Chaoborus & $15.6 \pm 20.7$ & $10.9 \pm 18.4$ & $4.6 \pm 14.8$ & $1.3 \pm 5.4$ \\
\hline Insects & $6.8 \pm 9.8$ & $4.8 \pm 8.7$ & $24.3 \pm 30.1$ & $20.4 \pm 30$ \\
\hline Molluscs & 0 & $0.6 \pm 2.7$ & 0 & $0.5 \pm 1.4$ \\
\hline Shrimps & 0 & $6.4 \pm 15$ & 0 & $13.6 \pm 25.4$ \\
\hline Fish & $0.4 \pm 1.4$ & $15 \pm 16$ & 0 & $10.8 \pm 22.7$ \\
\hline Others & $3.5 \pm 9.4$ & $2.7 \pm 12$ & $2.2 \pm 8.7$ & $0.1 \pm 0.7$ \\
\hline
\end{tabular}

a H. pyrrhocephalus mainly fed on copepods, H. tanaos mainly fed on cladocerans

Data derived from: ${ }^{\text {b }}$ Katunzi et al. (2003); Kishe-Machumu (2012). ${ }^{\mathrm{c}}$ Kishe-Machumu (2012); ${ }^{\mathrm{d}}$ Van Oijen \& Witte (1996); KisheMachumu (2012). ${ }^{\text {e }}$ Kishe-Machumu (2012)

(Mugidde et al., 2003). The consequence of this intensification of nitrogen fixation is that particulate matter would be expected to have lower $\delta^{15} \mathrm{~N}$ values as a result of the intense $\mathrm{N}$ fixation of atmospheric nitrogen with $\delta^{15} \mathrm{~N}=0$ (Fogel \& Cifuentes, 1993; Hoering, 1955; Macko et al., 1987). On the other hand, $\delta^{13} \mathrm{C}$ values of $H$. pyrrhocephalus remained unchanged while more positive values were expected. In 2005 and 2006, the diet of $H$. pyrrhocephalus contained relatively less zooplankton than in the 1970 s (Table 7), which may explain the lack of change in $\delta^{13} \mathrm{C}$ values of the contemporary $H$. pyrrhocephalus population if the $\mathrm{C}$ in zooplankton is based on a different phytoplankton source than in fish (dagaa) and insects. The contemporary H. pyrrhocephalus specimens were collected at relatively shallow stations (5.5-9.5 m), while the fish from the historic ecosystem have been caught at relatively deeper locations, north and south of the transect $(6-18 \mathrm{~m})$ which could explain the relatively low $\delta^{13} \mathrm{C}$ values. However, van Rijssel et al. (2016) reported similar $\delta^{13} \mathrm{C}$ values for $H$. pyrrhocephalus caught in 2006 at the deep station $\mathrm{G}$ $(14 \mathrm{~m})$ which would imply a dietary influence on these $\delta^{13} \mathrm{C}$ values.

Stable isotopes of the contemporary $H$. tanaos population did, surprisingly, not differ from the historic population, whereas they did shift their diet towards more fish, insects and midge larvae in the 2000s (Table 7). However, interpretation may again be confounded by the species changing habitats to exploit different food resources. All the $H$. tanaos caught in the historic system came from the shallow Butimba Bay (station B) while, except for one individual, all the H. tanaos caught in the contemporary system came from deeper stations within the Mwanza Gulf (Table S3). If the contemporary $H$. tanaos population had been caught in Butimba Bay, they might have had higher $\delta^{13} \mathrm{C}$ and lower $\delta^{15} \mathrm{~N}$ values, but as the population extended their habitat to deeper water in the 2000s (Kishe-Machumu et al., 2015), the fish moved along a gradient in stable isotope composition of their basal food resources and remained similar in isotopic composition to the values in the historic system. In contrast, van Rijssel et al. (2016) found an increase of $\delta^{15} \mathrm{~N}$ values in $H$. tanaos specimens caught in 2006 at station E $(6 \mathrm{~m})$ compared to fish caught in the early 1980 s at station B (4-6 m) and contributed this to increased uptake of fish (dagaa) of $H$. tanaos. Although many species in the contemporary system are morphologically similar to their ancestors in the historic ecosystem (van Rijssel \& Witte, 2013), they are displaying different diets and 
some are exploiting different habitats (KisheMachumu et al., 2008; Kishe-Machumu et al., 2015). These habitat and diet shifts can be explained by the change in availability of food types, loss of competition with trophic specialists, a decrease in water clarity or a combination of these factors (KisheMachumu et al., 2008).

Broadening of the diet spectrum is a common response to environmental stress in fish and has been reported for several other African lake fish including the cyprinid Rastrineobola argentea (locally known as dagaa, Wanink, 1998), the characid Brycinus sadleri (Wanink \& Joordens, 2007), the cichlids Oreochromis niloticus (Njiru et al., 2004) and Tilapia zillii (Muchiri et al., 1995) and for cichlids in Lake Kivu (Villanueva et al., 2008) and Lake Chivero (Zengeya \& Marshall, 2007). If eutrophication is responsible for the observed dietary overlap, continued eutrophication can have major implications for species diversity in Lake Victoria and other African lakes. The reduced water transparency inflicted by eutrophication interferes with mate choice, hampers sexual selection, and is thereby disrupting diversification mechanisms (Seehausen et al., 1997a). In addition, visual predators like cichlids depend on optical characteristics of the water and the conspicuousness of the prey (Seehausen et al., 2003). The reduced water transparency could therefore reduce the fish's choosiness, as the encounter rate with preferred prey types decreases (Seehausen et al., 2003), which could hamper trophic diversification by natural selection. Although the other African Great Lakes have not reached the level of eutrophication of Lake Victoria (Bootsma \& Hecky, 1993; Hecky, 1993), eutrophication has been observed in some regions of these lakes (Chale, 2003; Hecky et al., 2003; Otu et al., 2011). By adequately monitoring these lakes, we can improve our understanding of the effects of eutrophication on biodiversity and, with reductions in nutrient loading, moderate biodiversity losses in Lake Victoria and prevent biodiversity crises in other African lakes.

\section{Conclusions}

Our findings suggest that preserved cichlid specimens may be used for stable isotope analysis as preservation only affected $\delta^{13} \mathrm{C}$ and $\delta^{15} \mathrm{~N}$ values by $0.34-0.66 \%$, while the magnitude of changes over time and among species was much larger. This confirms the conclusions of Campbell et al. (2003) explaining that stable isotope analyses are a robust tool to study trophic positions and dietary sources in Lake Victoria. Many museums have substantial historical archives of preserved fish specimens. Therefore, this study supports the possibility of using archived collections to characterize food web structures of aquatic ecosystems at scales of tens to hundreds of years (Vander Zanden et al., 2003; Schmidt et al., 2009; Nakazawa et al., 2010).

This study revealed that significant differences, both in $\delta^{13} \mathrm{C}$ and $\delta^{15} \mathrm{~N}$ values of the historic ecosystem, exist among haplochromine trophic groups as well as among species in agreement with their diets. Species in the historic ecosystem had a much more distinct stable isotope composition indicating relatively strong fidelity to, or less availability of, particular food resources compared to species of the contemporary ecosystem.

In the contemporary ecosystem, stable isotope composition of the same species or assumed trophic groups, was much less distinct suggesting greater overlap in diets. Our data imply higher $\delta^{13} \mathrm{C}$ values for some fish species collected at littoral stations compared to those from deeper sublittoral stations, suggesting that at least some haplochromine species of the contemporary ecosystem are fairly stenotopic.

There was a general shift in $\delta^{13} \mathrm{C}$ values for most species between the historic and contemporary ecosystem which would be expected from the eutrophication of the lake and increase in the $\delta^{13} \mathrm{C}$ value composition of phytoplankton and detritus. The $\delta^{15} \mathrm{~N}$ values for two out of three species increased between the historic and contemporary ecosystem. Based on previous stomach and gut content analyses for these species, this increase is consistent with diet changes towards prey of higher trophic levels.

Acknowledgements This project was financially supported by the Netherlands Foundation for the Advancement of Tropical Research (WOTRO) Grants W87-129, W87-161, W87-189, W84-282, W84-488, WB84-587), the Netherlands Organization for International Cooperation in Higher Education (NUFFIC), the International Foundation for Science (IFS) and the Schure Beijerinck-Popping Fonds. A National Scientific and Engineering Research Council (NSERC) Discovery Grant to R.E. Hecky funded the stable isotope analyses. We are grateful to all institutions mentioned above for their support. We would like to thank two anonymous reviewers for their constructive comments. We also extend our thanks to the crew members, 
Mhoja Kayeba, Mohammed Haruna, Rajabu Machage and the late Aloys Peter, for their assistance during field work. We are indebted to Tom de Jong who provided us with statistical advice.

Open Access This article is distributed under the terms of the Creative Commons Attribution 4.0 International License (http:// creativecommons.org/licenses/by/4.0/), which permits unrestricted use, distribution, and reproduction in any medium, provided you give appropriate credit to the original author(s) and the source, provide a link to the Creative Commons license, and indicate if changes were made.

\section{References}

Arrington, D. A. \& K. O. Winemiller, 2002. Preservation effects on stable isotope analysis of fish muscle. Transactions of the American Fisheries Society 131(2): 337-342.

Balirwa, J. S., C. A. Chapman, L. J. Chapman, I. G. Cowx, K. Geheb, L. Kaufman, R. H. Lowe-McConnell, O. Seehausen, J. H. Wanink, R. L. Welcomme \& F. Witte, 2003. Biodiversity and fishery sustainability in the Lake Victoria Basin: an unexpected marriage? Bioscience 53(8): 703-715.

Bootsma, H. A. \& R. E. Hecky, 1993. Conservation of the African great lakes - a limnological perspective. Conservation Biology 7(3): 644-656.

Campbell, L. M., R. E. Hecky \& S. B. Wandera, 2003. Stable isotope analyses of food web structure and fish diet in Napoleon and Winam Gulfs, Lake Victoria, east Africa. Journal of Great Lakes Research 29: 243-257.

Campbell, L., R. E. Hecky, D. G. Dixon \& L. J. Chapman, 2006. Food web structure and mercury transfer in two contrasting Ugandan highland crater lakes (East Africa). African Journal of Ecology 44(3): 337-346.

Chale, F. M. M., 2003. Eutrophication of Kigoma Bay, Lake Tanganyika, Tanzania. Tanzania Journal of Science 29(1): 17-24.

Cornelissen, I. J. M., G. M. Silsbe, J. A. J. Verreth, E. van Donk \& L. A. J. Nagelkerke, 2014. Dynamics and limitations of phytoplankton biomass along a gradient in Mwanza Gulf, southern Lake Victoria (Tanzania). Freshwater Biology 59(1): 127-141.

de Zeeuw, M. P., M. Mietes, P. Niemantsverdriet, S. ter Huurne $\&$ F. Witte, 2010. Seven new species of detritivorous and phytoplanktivorous haplochromines from Lake Victoria. Zoologische Mededelingen (Leiden) 84: 201-250.

Dudgeon, D., A. H. Arthington, M. O. Gessner, Z. Kawabata, D. J. Knowler, C. Leveque, R. J. Naiman, A. H. PrieurRichard, D. Soto, M. L. Stiassny \& C. A. Sullivan, 2006. Freshwater biodiversity: importance, threats, status and conservation challenges. Biological Reviews of the Cambridge Philosophical Society 81(2): 163-182.

Eby, L. A., W. J. Roach, L. B. Crowder \& J. A. Stanford, 2006. Effects of stocking-up freshwater food webs. Trends in Ecology and Evolution 21(10): 576-584.

Flecker, A. S. \& C. R. Townsend, 1994. Community-wide consequences of trout introduction in New-Zealand streams. Ecological Applications 4(4): 798-807.
Fogel, M. L. \& L. A. Cifuentes, 1993. Isotope fractionation during primary production. In Engel, M. H. \& S. A. Macko (eds), Organic Geochemistry: Principles and Applications. Springer, Boston: 73-98.

France, R. L., 1995. C13 Enrichment in benthic compared to planktonic algae - foodweb implications. Marine Ecology 124(1-3): 307-312.

Francey, R. J., C. E. Allison, D. M. Etheridge, C. M. Trudinger, I. G. Enting, M. Leuenberger, R. L. Langenfelds, E. Michel \& L. P. Steele, 1999. A 1000-year high precision record of $\delta^{13} \mathrm{C}$ in atmospheric $\mathrm{CO}_{2}$. Tellus B 51(2): 170-193.

Gearing, J. N., 1991. The study of diet and trophic relationships through natural abundance ${ }^{13}$ C. In Coleman, D. C. \& B. Fry (eds), Carbon Isotope Techniques. Academic Press, San Diego: 201-218.

Goldschmidt, T., 1989. Reproductive strategies, subtrophic niche differentiation and the role of competition for food in haplochromine cichlids (Pisces) from Lake Victoria, Tanzania. Annales du Museé Royal de l'Afrique Centrale, Sciences Zoologiques 257: 199-232.

Goldschmidt, T., F. Witte \& J. Wanink, 1993. Cascading effects of the introduced Nile perch on the detritivorous phytoplanktivorous species in the sublittoral areas of Lake Victoria. Conservation Biology 7(3): 686-700.

Gonzalez-Bergonzoni, I., N. Vidal, B. X. Wang, D. Ning, Z. W. Liu, E. Jeppesen \& M. Meerhoff, 2015. General validation of formalin-preserved fish samples in food web studies using stable isotopes. Methods in Ecology and Evolution 6(3): 307-314.

Goudswaard, K. P. C., F. Witte \& J. H. Wanink, 2006. The shrimp Caridina nilotica in Lake Victoria (East Africa), before and after the Nile perch increase. Hydrobiologia 563: 31-44.

Hecky, R. E., 1993. The eutrophication of Lake Victoria. Verhandlungen der Internationalen Vereinigung für Theoretische und Angewandte Limnologie 25: 39-48.

Hecky, R. E. \& R. H. Hesslein, 1995. Contributions of benthic algae to lake food webs as revealed by stable isotope analysis. Journal of the North American Benthological Society 14(4): 631-653.

Hecky, R. E., F. W. B. Bugenyi, P. Ochumba, J. F. Talling, R. Mugidde, M. Gophen \& L. Kaufman, 1994. Deoxygenation of the deep water of Lake Victoria, East-Africa. Limnology and Oceanography 39(6): 1476-1481.

Hecky, R. E., H. A. Bootsma \& M. L. Kingdon, 2003. Impact of land use on sediment and nutrient yields to Lake Malawi/ Nyasa (Africa). Journal of Great Lakes Research 29: 139-158.

Hecky, R. E., R. Mugidde, P. S. Ramlal, M. R. Talbot \& G. W. Kling, 2010. Multiple stressors cause rapid ecosystem change in Lake Victoria. Freshwater Biology 55: 19-42.

Heino, J., R. Virkkala \& H. Toivonen, 2009. Climate change and freshwater biodiversity: detected patterns, future trends and adaptations in northern regions. Biological Reviews of the Cambridge Philosophical Society 84(1): 39-54.

Hesslein, R. H., K. A. Hallard \& P. Ramlal, 1993. Replacement of sulfur, carbon, and nitrogen in tissue of growing broad whitefish (Coregonus nasus) in response to a change in diet traced by $\delta^{34} \mathrm{~S}, \delta^{13} \mathrm{C}$ and $\delta^{15} \mathrm{~N}$. Canadian Journal of Fisheries and Aquatic Sciences 50(10): 2071-2076. 
Hoering, T., 1955. Variations of nitrogen-15 abundance in naturally occurring substances. Science 122(3182): 1233-1234.

Kaehler, S. \& E. A. Pakhomov, 2001. Effects of storage and preservation on the delta $\mathrm{C}-13$ and delta $\mathrm{N}-15$ signatures of selected marine organisms. Marine Ecology Progress Series 219: 299-304.

Katunzi, E. F. B., J. Zoutendijk, T. Goldschmidt, J. H. Wanink \& F. Witte, 2003. Lost zooplanktivorous cichlid from Lake Victoria reappears with a new trade. Ecology of Freshwater Fish 12(4): 237-240.

Kaufman, L., 1992. Catastrophic change in species rich fresh water ecosystems. Bioscience 42(11): 846-858.

Keeley, J. E. \& D. R. Sandquist, 1992. Carbon - fresh-water plants. Plant Cell and Environment 15(9): 1021-1035.

Keeling, C. D., 1979. The suess effect: ${ }^{13}$ carbon- ${ }^{14}$ carbon interrelations. Environment International 2: 229-300.

Kelly, B., J. B. Dempson \& M. Power, 2006. The effects of preservation on fish tissue stable isotope signatures. Journal of Fish Biology 69(6): 1595-1611.

Kishe-Machumu, M. A., 2012. Inter-guild differences and possible causes of the recovery of cichlid species in Lake Victoria, Tanzania $\mathrm{PhD}$ thesis, Leiden University.

Kishe-Machumu, M., J. Wanink \& F. Witte, 2008. Dietary shift in benthivorous cichlids after the ecological changes in Lake Victoria. Animal Biology 58(4): 401-417.

Kishe-Machumu, M. A., J. C. van Rijssel, J. H. Wanink \& F. Witte, 2015. Differential recovery and spatial distribution pattern of haplochromine cichlids in the Mwanza Gulf of Lake Victoria. Journal of Great Lakes Research 41(2): 454-462.

Kling, H. J., R. Mugidde \& R. E. Hecky, 2001. Recent changes in the phytoplankton community of Lake Victoria in response to eutrophication. In Munawar, M. \& R. E. Hecky (eds), The Great Lakes of the World (GLOW) - Food Web, Health and Integrity. Backhuys Publishers, Leiden: 47-65.

Lau, D. C. P., K. M. Y. Leung \& D. Dudgeon, 2012. Preservation effects on $\mathrm{C} / \mathrm{N}$ ratios and stable isotope signatures of freshwater fishes and benthic macroinvertebrates. Limnology and Oceanography: Methods 10(2): 75-89.

Macko, S. A., M. L. Fogel, P. E. Hare \& T. C. Hoering, 1987. Isotopic fractionation of nitrogen and carbon in the synthesis of amino-acids by microorganisms. Chemical Geology 65(1): 79-92.

Mbabazi, D., R. Ogutu-Ohwayo, S. B. Wandera \& Y. Kiziito, 2004. Fish species and trophic diversity of haplochromine cichlids in the Kyoga satellite lakes (Uganda). African Journal of Ecology 42(1): 59-68.

Muchiri, S. M., P. J. B. Hart \& D. M. Harper, 1995. The persistence of two introduced tilapia species in Lake Naivasha, Kenya, in the face of environmental variability and fishing pressure. In Pitcher, T. J. \& P. J. B. Hart (eds), The Impact of Species Changes in African Lakes. Springer, The Netherlands: 299-319.

Mugidde, R., 1992. Changes in phytoplankton productivity and biomass in Lake Victoria (Uganda). University of Waterloo.

Mugidde, R., 1993. The increase in phytoplankton primary productivity and biomass in Lake Victoria (Uganda). Verhandlungen der Internationalen Vereinigung für Theoretische und Angewandte Limnologie 25: 846-849.
Mugidde, R., R. E. Hecky, L. L. Hendzel \& W. D. Taylor, 2003. Pelagic nitrogen fixation in Lake Victoria (East Africa). Journal of Great Lakes Research 29: 76-88.

Nakazawa, T., Y. Sakai, C. H. Hsieh, T. Koitabashi, I. Tayasu, N. Yamamura \& N. Okuda, 2010. Is the relationship between body size and trophic niche position time-invariant in a predatory fish? First stable isotope evidence. PLoS ONE 5(2): e9120.

Njiru, M., J. B. Okeyo-Owuor, M. Muchiri \& I. G. Cowx, 2004. Shifts in the food of Nile tilapia, Oreochromis niloticus (L.) in Lake Victoria, Kenya. African Journal of Ecology 42(3): 163-170.

Ochumba, P. B. O. \& D. I. Kibaara, 1989. Observations on bluegreen algal blooms in the open waters of Lake Victoria, Kenya. African Ecology 27(1): 23-34.

Ogawa, N. O., T. Koitabashi, H. Oda, T. Nakamura, N. Ohkouchi \& E. Wada, 2001. Fluctuations of nitrogen isotope ratio of gobiid fish (Isaza) specimens and sediments in Lake Biwa, Japan, during the 20th century. Limnology and Oceanography 46(5): 1228-1236.

Ojwang, W. O., L. Kaufman, A. A. Asila, S. Agembe \& B. Michener, 2004. Isotopic evidence of functional overlap amongst the resilient pelagic fishes of Lake Victoria, Kenya. Hydrobiologia 529(1): 27-35.

Ojwang, W. O., L. Kaufman, E. Soule \& A. A. Asila, 2007. Evidence of stenotopy and anthropogenic influence on carbon source for two major riverine fishes of the Lake Victoria watershed. Journal of Fish Biology 70(5): 1430-1446.

Ojwang, W. O., J. E. Ojuok, D. Mbabazi \& L. Kaufman, 2010. Ubiquitous omnivory, functional redundancy and the resiliency of Lake Victoria fish community. Aquatic Ecosystem Health and Management 13(3): 269-276.

Otu, M. K., P. Ramlal, P. Wilkinson, R. I. Hall \& R. E. Hecky, 2011. Paleolimnological evidence of the effects of recent cultural eutrophication during the last 200 years in Lake Malawi, East Africa. Journal of Great Lakes Research 37: 61-74.

Ponsard, S. \& M. Amlou, 1999. Effects of several preservation methods on the isotopic content of Drosophila samples. Comptes Rendus De L Academie Des Sciences Serie IiiSciences De La Vie 322(1): 35-41.

Poste, A. E., D. C. G. Muir, D. Mbabazi \& R. E. Hecky, 2012. Food web structure and mercury trophodynamics in two contrasting embayments in northern Lake Victoria. Journal of Great Lakes Research 38(4): 699-707.

Poste, A. E., R. E. Hecky \& S. J. Guildford, 2013. Phosphorus enrichment and carbon depletion contribute to high $\mathrm{Mi}$ crocystis biomass and microcystin concentrations in Ugandan lakes. Limnology and Oceanography 58(3): 1075-1088.

Poste, A. E., D. C. Muir, S. J. Guildford \& R. E. Hecky, 2015. Bioaccumulation and biomagnification of mercury in African lakes: the importance of trophic status. Science of the Total Environment 506-507: 126-136.

Pringle, R. M., 2005. The origins of the Nile perch in Lake Victoria. Bioscience 55(9): 780-787.

R development Core Team. 2016. R: A Language and Environment for Statistical Computing. R Foundation for Statistical Computing, Vienna, Austria. http://www.r-project. org/. 
Sarakinos, H. C., M. L. Johnson \& M. J. Vander Zanden, 2002. A synthesis of tissue-preservation effects on carbon and nitrogen stable isotope signatures. Canadian Journal of Zoology 80(2): 381-387.

Schmidt, S. N., M. J. Vander Zanden \& J. F. Kitchell, 2009. Long-term food web change in Lake Superior. Canadian Journal of Fisheries and Aquatic Sciences 66(12): 2118-2129.

Schwartz, J. D. M., M. J. Pallin, R. H. Michener, D. Mbabazi \& L. Kaufman, 2006. Effects of Nile perch, Lates niloticus, on functional and specific fish diversity in Uganda's Lake Kyoga system. African Journal of Ecology 44(2): 145-156.

Seehausen, O., 1996. Lake Victoria rock cichlids: taxonomy, ecology, and distribution. Verduyn cichlids, Zevenhuizen.

Seehausen, O., J. J. M. van Alphen \& F. Witte, 1997a. Cichlid fish diversity threatened by eutrophication that curbs sexual selection. Science 277(5333): 1808-1811.

Seehausen, O., F. Witte, E. F. Katunzi, J. Smits \& N. Bouton, 1997b. Patterns of the remnant cichlid fauna in southern Lake Victoria. Conservation Biology 11(4): 890-904.

Seehausen, O., J. Van Alphen \& F. Witte, 2003. Implications of eutrophication for fish vision, behavioral ecology and species coexistence. In Chrisman, T., L. Chapman \& C. Chapman (eds), Aquatic Conservation and Management in Africa. University Press of Florida, Gainesville: 266-287.

Silsbe, G. M., R. E. Hecky, S. J. Guildford \& R. Mugidde, 2006. Variability of chlorophyll a and photosynthetic parameters in a nutrient-saturated tropical great lake. Limnology and Oceanography 51(5): 2052-2063.

Simon, K. S. \& C. R. Townsend, 2003. Impacts of freshwater invaders at different levels of ecological organisation, with emphasis on salmonids and ecosystem consequences. Freshwater Biology 48(6): 982-994.

Smith, V. H. \& D. W. Schindler, 2009. Eutrophication science: where do we go from here? Trends in Ecology and Evolution 24(4): 201-207.

Smith, F. A. \& N. A. Walker, 1980. Photosynthesis by aquatic plants - Effects of unstirred layers in relation to assimilation of $\mathrm{CO}_{2}$ and $\mathrm{HCO}_{3}^{-}$and to carbon isotopic discrimination. New Phytologist 86(3): 245-259.

Stager, J. C., R. E. Hecky, D. Grzesik, B. F. Cumming \& H. Kling, 2009. Diatom evidence for the timing and causes of eutrophication in Lake Victoria, East Africa. Hydrobiologia 636(1): 463-478.

Sweeting, C. J., N. V. C. Polunin \& S. Jennings, 2004. Tissue and fixative dependent shifts of delta $\mathrm{C}-13$ and delta $\mathrm{N}-15$ in preserved ecological material. Rapid Communications in Mass Spectrometry 18(21): 2587-2592.

van Oijen, M. J. P. \& F. Witte, 1996. Taxonomical and ecological description of a species complex of zooplanktivorous and insectivorous cichlids from Lake Victoria. Zool Verh Leiden 302: 1-56.

van Rijssel, J. C. \& F. Witte, 2013. Adaptive responses in resurgent Lake Victoria cichlids over the past 30 years. Evolutionary Ecology 27(2): 253-267.

van Rijssel, J. C., E. S. Hoogwater, M. A. Kishe-Machumu, E. van Reenen, K. V. Spits, R. C. van der Stelt, J. H. Wanink $\&$ F. Witte, 2015. Fast adaptive responses in the oral jaw of Lake Victoria cichlids. Evolution 69(1): 179-189.

van Rijssel, J. C., R. E. Hecky, M. A. Kishe-Machumu \& F. Witte, 2016. Changing ecology of Lake Victoria cichlids and their environment: evidence from $\mathrm{C}^{13}$ and $\mathrm{N}^{15}$ analyses. Hydrobiologia. doi 10.1007/s10750-016-2790-y.

Vander Zanden, M. J., J. M. Casselman \& J. B. Rasmussen, 1999. Stable isotope evidence for the food web consequences of species invasions in lakes. Nature 401(6752): 464-467.

Vander Zanden, M. J., S. Chandra, B. C. Allen, J. E. Reuter \& C. R. Goldman, 2003. Historical food web structure and restoration of native aquatic communities in the Lake Tahoe (California-Nevada) basin. Ecosystems 6(3): 274-288.

Vander Zanden, M. J., J. D. Olden \& C. Gratton, 2006. Foodweb approaches in restoration ecology. In Falk, D. A., M. A. Palmer \& J. B. Zedler (eds), Foundations of Restoration Ecology. Island Press, Washington, D. C.: 165-189.

Verburg, P., 2007. The need to correct for the Suess effect in the application of $\delta^{13} \mathrm{C}$ in sediment of autotrophic Lake Tanganyika, as a productivity proxy in the Anthropocene. Journal of Paleolimnology 37(4): 591-602.

Villanueva, M. C. S., M. Isumbisho, B. Kaningini, J. Moreau \& J.-C. Micha, 2008. Modeling trophic interactions in Lake Kivu: what roles do exotics play? Ecological Modelling 212(3-4): 422-438.

Vonlanthen, P., D. Bittner, A. G. Hudson, K. A. Young, R. Muller, B. Lundsgaard-Hansen, D. Roy, S. Di Piazza, C. R. Largiader \& O. Seehausen, 2012. Eutrophication causes speciation reversal in whitefish adaptive radiations. Nature 482(7385): 357-362.

Vuorio, K., M. Meili \& J. Sarvala, 2006. Taxon-specific variation in the stable isotopic signatures $\left(\delta^{13} \mathrm{C}\right.$ and $\left.\delta^{15} \mathrm{~N}\right)$ of lake phytoplankton. Freshwater Biology 51(5): 807-822.

Wanink, J. H., 1998. The pelagic cyprinid Rastrineobola argentea as a crucial link in the disrupted ecosystem of Lake Victoria Dwarfs and Giants - African Adventures. PhD Thesis, Leiden University, Leiden.

Wanink, J. H., 1999. Prospects for the fishery on the small pelagic Rastrineobola argentea in Lake Victoria. Hydrobiologia 407: 183-189.

Wanink, J. H. \& J. C. A. Joordens, 2007. Dietary shifts in Brycinus sadleri (Pisces: Characidae) from southern Lake Victoria. Aquatic Ecosystem Health and Management 10(4): 392-397.

Winemiller, K. O., 1989. Ontogenetic diet shifts and resource partitioning among piscivorous fishes in the Venezuelan Llanos. Environmental Biology of Fishes 26(3): 177-199.

Witte, F., 1981. Initial results of the ecological survey of the haplochromine cichlid fishes from the Mwanza Gulf of Lake Victoria (Tanzania) - breeding patterns, trophic and species distribution - with recommendations for commercial trawl-fishery. Netherlands Journal of Zoology 31(1): 175-202.

Witte, F. \& M. J. P. Van Oijen, 1990. Taxonomy, ecology and fishery of haplochromine trophic groups. Zool Verh Leiden 262: 1-47.

Witte, F., T. Goldschmidt, P. C. Goudswaard, W. Ligtvoet, M. J. P. van Oijen \& J. H. Wanink, 1992a. Species extinction and concomitant ecological changes in Lake Victoria. Netherlands Journal of Zoology 42(2-3): 214-232.

Witte, F., T. Goldschmidt, J. H. Wanink, M. J. P. van Oijen, K. P. C. Goudswaard, E. Witte-maas \& N. Bouton, 1992b. The destruction of an endemic species flock - quantitative data 
on the decline of the haplochromine cichlids of Lake Victoria. Environmental Biology of Fishes 34(1): 1-28.

Witte, F., B. S. Msuku, J. H. Wanink, O. Seehausen, E. F. B. Katunzi, K. P. C. Goudswaard \& T. Goldschmidt, 2000. Recovery of cichlid species in Lake Victoria: an examination of factors leading to differential extinction. Reviews in Fish Biology and Fisheries 10(2): 233-241.

Witte, F., J. H. Wanink, H. A. Rutjes, H. J. Van der Meer \& G. E. E. J. M. Van Den Thillart, 2005. Eutrophication and its influence on the the fish fauna of Lake Victoria. In Reddy, M. V. (ed.), Restoration and Management of Tropical
Eutrophic Lakes. Science Publishers Inc., Enfield (NH): 301-338.

Witte, F., J. H. Wanink \& M. A. Kishe, 2007. Species distinction and the biodiversity crisis in Lake Victoria. Transactions of the American Fisheries Society 136: 1146-1159.

Woodward, G. U. Y., 2009. Biodiversity, ecosystem functioning and food webs in fresh waters: assembling the jigsaw puzzle. Freshwater Biology 54(10): 2171-2187.

Zengeya, T. A. \& B. E. Marshall, 2007. Trophic interrelationships amongst cichlid fishes in a tropical African reservoir (Lake Chivero, Zimbabwe). Hydrobiologia 592(1): 175-182. 